\title{
FMOD Gene
}

National Cancer Institute

\section{Source}

National Cancer Institute. FMOD Gene. NCI Thesaurus. Code C104391.

This gene may play a role in the assembly of the extracellular matrix. 